\section{Destruição e} proteção da

Mata Atlântica no

Rio de Janeiro:

ensaio bibliográfico

acerca da

eco-história

\section{Destruction and}

protection of

Rio de Janeiro's

Atlantic Rain Forest:

a bibliograpbical

essay on eco-bistory
SOFFIATTI, A.: 'Destruição e proteção da Mata Atlântica no Rio de Janeiro: ensaio bibliográfico acerca da eco-história'. História, Ciências, Saúde-Manguinhos, vol. IV(2): 309-327, jul.-out. 1997.

A partir da análise crítica do livro de José Augusto Drummond, Devastação e preservação ambiental no Rio de Janeiro, o autor faz um inventário dos investigadores, das questões e das fontes que configuram a eco-história, um campo recente de investigação que agora começa a aflorar na historiografia brasileira, obrigando-a a repensar em profundidade as relações entre ciências sociais e naturais, sociedade e biologia, homem e natureza.

Palavras-chaves: eco-história, história ambiental, ecorregião, Rio de Janeiro, Mata Atlântica.

SOFFIATTI, A.: 'Destruction and Protection of Rio de Janeiro's Atlantic Rain Forest: A bibliographical essay on eco-history'. História, Ciências, Saúde-Manguinhos, vol. IV(2):309-327, jul.-out. 1997.

Based on a critical analysis of José Augusto Drummond's book Devastação e preservação ambiental no Rio de Janeiro, the author of this article has compiled an inventory of the researchers, issues, and sources that are found within the field of eco-bistory. The appearance of this new area of research within Brazilian bistoriography has forced the discipline to seriously rethink relations between the social and natural sciences, society and biology, man and nature.

KEYWORDS: eco-history, environmental bistory, eco-region, Rio de Janeiro, Atlantic rain forest. 


\begin{abstract}
A Ifred Crosby (1993) examinou a constituição de neo-Europas na América e na Oceania, entendidas como tentativas de replicar o modo de vida europeu em territórios não-europeus mas similares a ele do ponto de vista ambiental e com população predominantemente européia. Sua atenção voltou-se, pois, para os Estados Unidos, o Canadá, a Argentina, o Uruguai, os três estados do Sul do Brasil, o Chile, a Austrália e a Nova Zelândia, sem deixar de fazer incursões no que denomino de neo-Europas mestiças, como as Américas portuguesa e hispânica. O mesmo autor já havia estudado uma fatia de uma destas neo-Europas (idem, 1973). Da mesma forma, Cronon (1983), em livro já clássico, tratou das profundas transformações produzidas pela invasão e ocupação européias em outra parte da neo-Europa norte-americana.

Quanto às neo-Europas mestiças, a produção em eco-história ainda é pequena. Com respeito aos ecossistemas situados no recorte político do estado nacional do Brasil, Dean (1996, 1989) deu-nos dois estudos panorâmicos: um sobre a Amazônia e outro sobre a Mata Atlântica. No âmbito deste bioma, Claudia Heynemann (1995) analisa particularmente o significado simbólico da floresta da Tijuca na capital de um país que pretendia ser reconhecido como membro da civilização (entendida, no século XIX, como civilização européia). De minha parte, elegi o segmento da Mata Atlântica situado entre os rios Macaé e Itabapoana - a ecorregião Norte-Noroeste fluminense - para investigar o processo de desmantelamento dos ecossistemas aquáticos continentais e dos ecossistemas vegetais nativos, bem como o empobrecimento da biodiversidade faunística nativa e a introdução de espécies vegetais e animais exóticas (Soffiati, 1996).

Agora, José Augusto Drummond, em Devastação e preservação ambiental no Rio de Janeiro, traz mais uma contribuição ao conhecimento deste bioma no território que acabou por receber, após longa história política, a denominação de estado do Rio de Janeiro, uma das unidades federadas de um estado nacional chamado Brasil, cujas origens se situam no Tratado de Tordesilhas, anterior mesmo à invasão perpetrada pelos portugueses, estado encravado num continente que os europeus batizaram de América. O autor divide sua obra em duas partes: na primeira, estuda as relações estabelecidas pelas antropossociedades ameríndias e pelas antropossociedades de origem européia com a natureza nãohumana; na segunda, examina os quatro parques nacionais criados no estado do Rio de Janeiro, a partir de 1937, a saber, os parques nacionais de Itatiaia, da Serra dos Órgãos, da Tijuca e da Serra da Bocaina. Embora o fulcro do livro sejam estas unidades de preservação/conservação classificadas de parque pela legislação brasileira, mais especificamente os parques criados e 'mantidos' pelo governo federal, Drummond traça o curso de um dos mais
\end{abstract}


colossais processos de remoção antrópica de florestas tropicais do planeta.

Como Crosby (1993), Dean (1996, 1989) e Soffiati (1996), Drummond trabalha com a longa duração. Parece que esta peculiaridade se explica pela relativa juventude da eco-história e dos vastos campos virgens e semivirgens que ela incorpora, como novo objeto, aos domínios da história. O eco-historiador parece comportar-se ainda como um pioneiro que sacrifica os pequenos recortes espaciais e temporais, que lhe permitiriam análise aprofundada, por vôos extensos, que o levam a reconhecer terreno e abrir caminho a outros pesquisadores. A exemplo de Crosby e Dean, Drummond escreve para um leitor leigo, embora não exclua o especialista. Este aspecto é de fundamental importância, ignorá-lo pode nos conduzir ao erro de exigir do autor o que ele não se comprometeu a dar.

Drummond produziu um texto fluente e bem redigido, em que as interlocuções e transcrições reduzem-se ao mínimo. Por trás dele entrevemos sua tese de mestrado, esta sim, uma investigação de grande envergadura destinada a especialistas (Drummond, 1988). Em trabalhos acadêmicos, a transcrição ou a supressão de falas requer cuidado muito especial. Por um lado, escritos repletos de transcrições cansam o leitor não familiarizado com os vezos da Academia e, ademais, muito freqüentemente dispensam o autor da tarefa da análise e interpretação. Por outro, transcrições bem colocadas podem conferir ao texto colorido especial, aumentando o atrativo para o leitor. Citar de menos constitui risco tão perigoso quanto citar demais. O escritor que adota perante as fontes e a bibliografia numa atitude de "deixa que eu falo por vocês" pode privar o leitor do prazer da confirmação através de uma sorte de retórica dialógica, tal como aquela preconizada por Chaim Perelman, José Américo Motta Pessanha e Edgar Morin. Como leitor ao mesmo tempo profissional e amador, confesso que senti falta de transcrições. Poderiam iluminar mais o livro de José Augusto Drummond, embora eu não duvide de sua condição de porta-voz abalizado.

Em breve e incisiva introdução, ele coloca o leitor a par dos postulados da história ambiental, que, em suas palavras, "está construindo, há cerca de 15 anos, o que considero uma nova modalidade de estudo, ligando a história natural à história social e, acima de tudo, vendo as interações entre ambas". Mais do que colocar a natureza na história, como propõe Cronon (1983), Drummond esforça-se em colocar a história humana no contexto da natureza não-humana. Além do mais, ele domina a bibliografia sobre este novo campo da história, lidando com segurança com os autores citados e ainda com Donald Worster, Richard White, Stephen Pyne, Joseph Petulla, Frederick Turner, Roderick Nash, Samuel Hays e Richard Tucker. Tem o mérito de conhecer bem a 
língua inglesa, o que lhe permitiu redigir nesse idioma suas teses de mestrado e de doutorado, e ainda traduzir Turner (1990) e revisar a tradução do livro de Dean (1996). Além de citar esses autores, Drummond apresenta ao leitor estudiosos que se mostraram sensíveis à questão ambiental, antes que ela se transformasse em campo de investigação autônoma. Assinala os historiadores Arnold Toynbee, Lewis Mumford, Gordon Childe, Walter Prescott Webb e Fernand Braudel; os antropólogos Claude Lévi-Strauss, Julian Steward, Marshall Sahlins; e os geógrafos Carl Sauer, Karl Ritter e Ratzel. No Brasil, especificamente, Sérgio Buarque de Holanda, Gilberto Freyre, Aziz Ab'Saber e Alberto Lamego dedicaram especial atenção ao contexto ambiental, mas é a Caio Prado Junior que Drummond confere a principal homenagem.

Entre as características básicas da história ambiental, o autor destaca o cruzamento com a história regional. De fato, os ecohistoriadores têm dado significativa contribuição ao esforço de restituir ao conceito de região a sua base natural, que foi anulada pelo culturalismo de alguns autores, notadamente os de formação marxista. Mesmo adotando um recorte político ou cultural em sua análise, como faz Drummond com o Rio de Janeiro, o ecohistoriador não perde de vista o suporte ecológico, seja ele conferido pelo relevo, pela rede hídrica, pelas formações vegetais nativas ou qualquer outro traço natural. No máximo, emprega o conceito de ecorregião proposto por Ignacy Sachs. Drummond enfrenta aí um problema comum aos eco-historiadores: uma ecorregião pode se dividir em microecorregiões ou se agrupar com outras em meso ou macroecorregiões. Warren Dean teve a seu favor a unidade complexa do Domínio Atlântico. Eu contei com dois limites físicos bem visíveis, os rios Macaé e Itabapoana, além da linha de costa e as serras do Mar e da Mantiqueira. Drummond encontrou mais dificuldade para definir o recorte da sua ecorregião. "O território fluminense", explica ele, "se estende de leste a oeste, na forma de um retângulo fortemente 'dobrado' ao meio." Trabalhar com a longa duração sempre sujeita o historiador a anacronismos. Este retângulo fortemente dobrado só adquiriu tal formato com a definição das fronteiras, a princípio imprecisas, que separavam a capitania do Rio de Janeiro das capitanias de São Paulo e de Minas Gerais. A acentuada inflexão para o norte, formando um dos ângulo ao sul da figura geométrica entrevista por Drummond, é dada pelo cabo de São Tomé. Assim, os limites da 'meso-ecorregião', digamos, que Drummond denomina de Rio de Janeiro seriam, ao que parece, constituídos pela costa e pelos cursos do rio Paraíba do Sul e de alguns de seus afluentes. No mais, entendo que só as fronteiras políticas traçadas pela ocupação européia definiram uma unidade de resto inexistente e impensável para os povos nativos. Mesmo reconhecendo uma 
${ }^{1}$ Ver 'Descrição que faz o capitão Miguel Ayres Maldonado e o capitão Jozé de Castilho Pinto e seus companheiros dos trabalhos e fadigas das suas vidas, que tiveram nas conquistas da capitania do Rio de Janeiro e São Vicente, com a gentilidade e com os piratas nesta costa.' Revista do Instituto Histórico e Geográfico do Brasil, Rio de Janeiro, Imprensa Nacional, tomo XVIII, 1894. meso-ecorregião delineada pelo oceano Atlântico, ao sul, e pelo rio Paraíba, ao norte, o interior fica empobrecido, porquanto o autor não inclui nela, ao lado das províncias topográficas da planície costeira, da serra do Mar e do vale do Paraíba do Sul, a importante Formação Barreiras, de origem terciária.

Uma outra área apontada por Drummond no retângulo recurvado do Rio de Janeiro só tem merecido a atenção de geólogos e geomorfólogos e foi objeto de algumas controvérsias mais recentemente. Trata-se da extensa planície aluvial formada principalmente pelo rio Paraíba, no norte do retângulo. Warren Dean (1996) aventa a hipótese de que os campos herbáceos nativos ali encontrados pelos invasores europeus originaram-se do uso freqüente do fogo pelos índios goitacás. Drummond (1997, pp. 79, $81,127)$ considera-a uma planície de restinga. Certas passagens de seu livro não deixam dúvida quanto à confusão. "Os cronistas e historiadores das terras fluminenses, como Alberto Lamego em $O$ homem e o brejo, dão ênfase à localidade chamada Campo Limpo, nas imediações da atual cidade de Campos, na verdade um trecho de vegetação de restinga." Mais adiante: "Na localidade de Campo Limpo, as restingas serviram de pastos naturais com relativo sucesso." E nesta passagem diz: "As restingas, relativamente pequenas, eram usadas como precárias pastagens naturais."

Até que se efetuem estudos de palinologia, a existência de campos nativos na planície aluvial do Norte Fluminense explicase pelas cheias periódicas do rio Paraíba do Sul e da miríade de ecossistemas lagunares, que tornavam a área alagável durante boa parte do ano, só permitindo o desenvolvimento de vegetação arbórea nos cocurutos. Os sete fidalgos que reivindicaram esta planície como sesmarias, em 1627, já percebiam com nitidez as diferenças de solo entre a restinga e a baixada aluvial. ${ }^{1}$ Em 1785, o capitão cartógrafo Manoel Martins do Couto Reis mostrou, em mapa e relatório minuciosos, que os campos Limpo, da Boa Vista, de Santo Amaro, do Algodoeiro e do Taí, todos na planície de massapê, distinguiam-se claramente dos campos de Macaé, Jurubatiba, Carapebus, dos Sabões e de Jagoroaba, situados nas restingas ou em sua periferia.

Os campos de Macaé, que principiam no rio deste nome, Juribatiba e Carapebus; porque são em muita parte emboscados, não têm tanta aprazibilidade; são muito areentos, com poucos pastos, e menos fecundos ... . Os dos Sabões e Jagoroaba são dilatados e agradáveis mas defeituosos por cuja causa não admitem muito gado. Os da Boavista, S. Amaro, Algodoeiro e Taí são cheios de merecimento pela beleza dos seus pastos substanciais, e totalmente limpos. ... O Campo Limpo foi em tempo mais an-tigo igualmente perfeito; porém presentemente vai em decadência pela prodigiosa quantidade de limoeiros, que o têm infeccionado: a causa deste defeito é originada 
do uso geral de fazerem grandes cercas deste arvoredo: ele produz com excesso, o gado come-lhe o fruto, e o semeia no campo; e dali nasce a perniciosa abundância. A vassoura, a guaxima, a aroeira, e o algodoeiro silvestre ocasionam igual dano.

Alberto Ribeiro Lamego tratou da planície aluvial, cuja formação se efetuou no sentido continente-oceano, em O homem e o brejo, reservando $O$ homem e a restinga para esse tipo de terreno com formação no sentido oceano-continente. Em conjunto, ambos formam uma ampla planície flúvio-marinha, a baixada dos Goitacases, que avança mar adentro, afastando a costa da serra do Mar, e não o contrário.

Um segundo postulado da eco-história indicado por Drummond (1997) é o diálogo sistemático com quase todas as ciências naturais aplicáveis ao entendimento dos quadros físicos e ecológicos das regiões estudadas. "Os historiadores ambientais", afiança ele, "não fazem apenas visitas protocolares às ciências naturais: dependem delas para saber como funcionam os ecossistemas sem interferências humanas, para daí identificar com precisão os efeitos ecossistêmicos da ação humana." E no capítulo 8, em particular, demonstra seus conhecimentos seguros de edafologia, ecologia e agronomia. A meu ver esta é, talvez a parte mais bem-sucedida do livro. Com mestria, o autor mostra que o padrão de plantio do café acarretava intensa erosão das encostas, principalmente por ação das águas pluviais, perda ou transferência de solos férteis, assoreamento dos ecossistemas aquáticos continentais e turbidez dos rios outrora cristalinos. Além de revelar conhecimento minucioso das técnicas e tecnologias empregadas na cafeicultura, empreende magnífica análise econômica e sociológica desta planta exótica que tanto marcou a história do Brasil no século XIX.

A conclusão tardia e perversa para o meio ambiente é o verdadeiro desastre ecológico e econômico ocasionado pelo plantio de café em terrenos declivosos. E o mais grave é que tal lavoura continua a ser praticada em moldes não muito diferentes daqueles que arrasaram florestas, solos e águas no século XIX. Cabe perguntar se os cafeicultores percebiam os efeitos danosos do cultivo da Coffea arabica. Claro que sim, tanto ontem quanto hoje. Ontem, porém, a lógica do sistema econômico ignorava ou minimizava o papel do meio ambiente, concebendo-o como palco de uma peça representada por atores exclusivamente humanos ou como estoque de recursos infinitos a que se poderia recorrer mesmo quando a fertilidade de determinado terreno se esgotasse. Hoje, as terras livres, se não acabaram, tornaram-se muito limitadas. Por toda a parte a exaustão é um incômodo que segue acuando os agricultores. Apesar disso, acredita-se na possibilidade de repor a fertilidade do solo através de insumos químicos. Dean (1996) 
salienta que o café poderia ter sido melhor cultivado em sistema de sombreamento, como o cacau. Assim, tragicamente, milhares de hectares de florestas foram sacrificadas em vão.

Soa estranho a intenção de "identificar com precisão os efeitos ecossistêmicos da ação humana", já que, em se tratando de sistemas complexos, como os ecossistemas e as antropossociedades, a precisão é inatingível.

No diálogo sistemático com as ciências humanas acerca da natureza não-humana, noto que o eco-historiador José Augusto Drummond (1997, pp. 78-9) vale-se de uma classificação que não dá conta de toda a riqueza das formações vegetais nativas contidas na meso-ecorregião estudada. Segundo ele, "estudos geológicos, biológicos e climatológicos e a relativamente extensa literatura de exploradores e viajantes permitem estimar que o atual território fluminense, em torno do ano de 1500, estava em 92 a 95\% coberto de florestas úmidas, tropicais, latifoliadas e perenifólias." Completa o quadro dizendo que "os 5 a 8\% restantes eram cobertos por restingas e mangues, concentrados na orla costeira. ... As plantas (de restinga) são predominantemente gramíneas e ervas, com poucas plantas lenhosas (arbustos ou árvores) ... . É um tipo de vegetação hoje virtualmente inexistente na sua fisionomia natural, no Rio de Janeiro e em outros estados, exatamente por se localizar ao longo da acessível e muito usada faixa litorânea do país." Desde 1982, com o projeto RadamBrasil, vem ganhando incremento a tipologia proposta por Henrique Pimenta Veloso e sua equipe, que acaba por desembocar no chamado Domínio Mata Atlântica ou Província Atlântica, expressões ainda inadequadas. No interior deste grande bioma, na região do Rio de Janeiro, são identificados dois tipos de florestas: a ombrófila densa, que equivale à floresta latifoliada perenifólia registrada por Drummond, e a estacional, não mencionada pelo autor e que ocupava dilatadas extensões da margem esquerda do rio Paraíba do Sul, na parte noroeste do retângulo dobrado. O Domínio Mata Atlântica abarca ainda os ecossistemas associados, como os campos de altitude (entendidos como refúgio ecológico), as formações vegetais nativas de restinga, os manguezais e a vegetação de brejos e lezírias (as três classificadas como formações pioneiras). O polêmico Decreto Federal $n^{\circ}$ 750, de 10.2.1993, adotou esta tipologia.

Longe de mim cobrar de José Augusto Drummond o emprego de uma tipologia que só ganhou consistência a partir de 1991, com os trabalhos de Veloso, Rangel Filho e Lima, sabendo-se que Devastação e preservação ambiental no Rio de Janeiro é uma síntese da tese de mestrado do autor, datada de 1988. Ainda assim, sou de opinião que as florestas estacionais não poderiam ficar de fora, pois de há muito ganharam estatuto próprio com o nome de floresta caducifólia (Golfari e Moosmayer, s. d.). Com respeito às formações 
vegetais nativas de restinga, o quadro é bem mais complexo. Não apenas as constituem gramíneas e ervas, senão que existe um zoneamento, da costa para o interior, em que se pode discernir vegetação herbácea reptante, vegetação arbustiva, vegetação arbustivo-arbórea e vegetação arbórea, sem contar com a vegetação higrófila que medra nas depressões intercordões. Este quadro pode ainda ser contemplado na restinga que se estende do rio Macaé à Barra do Furado, por mais que este bioma tenha sido um dos mais afetados pela invasão e ocupação européias da parte do continente batizada de Brasil e, dentro dela, da meso-ecorregião que corresponde ao estado do Rio de Janeiro.

Se me permitem mais uma confissão, senti falta, deveras, de um capítulo que tratasse da autoconstrução do Domínio Mata Atlântica antes que fosse atingido por duas levas de invasores: a dos chamados ameríndios e a dos europeus. Senti falta de um capítulo dedicado só a este palco-ator do drama em que protagoniza a principal vítima, tal como os veados da floresta de Windsor, estudados por Thompson (1987).

Ainda no âmbito do diálogo interciências, é notória a influência de Oliveira Vianna, Caio Prado Júnior, Gilberto Freyre e Sérgio Buarque de Holanda no quadro construção que José Augusto Drummond constrói da sociedade e da economia brasileiras entre os séculos XVI e XIX. O Brasil é visto como grande colônia de exploração de Portugal em que vigora o famoso tripé latifúndiotrabalho escravo-monocultura para exportação. Completam o quadro a ausência de pequenos proprietários estáveis e independentes, um catolicismo devoto e intolerante (embora não necessariamente fervoroso), a submissão do indígena convertido ou a expulsão do recalcitrante para o interior. Num parágrafo, sintetiza esta filiação historiográfica (pp. 61-3):

O latifúndio restringiu (e em muitas regiões praticamente eliminou) a pequena e média propriedades e, conseqüentemente, a formação de uma classe de pequenos e médios proprietários estáveis que talvez usasse a terra de forma mais prudente ou menos predatória. A monocultura latifundiária de exportação, trabalhada pela mão-de-obra escrava, submeteu extensos trechos das terras brasileiras à lógica comercial européia, induzindo a exploração intensiva de larga escala. Ela impediu a emergência de grupos sociais propriamente camponeses incumbidos de manter ou recuperar a fertilidade da terra trabalhando em escala menor ou de subsistência. ... O uso intensivo do trabalho escravo, a falta de pequenos proprietários estáveis e a disponibilidade aparentemente infinita de terras novas na nova colônia conspiravam contra o uso prudente das extensas terras brasileiras.

A partir da década de 1980, um grupo de jovens historiadores, sob a inspiração de Maria Yedda Linhares e Ciro Flammarion Cardoso 
${ }^{2}$ Entre estes historiadores, menciono Castro (1995, 1987); Florentino, (1997); Fragoso (1992, 1983); Fragoso e Florentino (1993); Gorenstein (1978); Lara (1988); Lenharo (1979); Martins (1983); Motta (1989); Muniz (1979); Schwartz, (1988); Mello e Souza, (1986); Castro Faria, (1994,1986).

${ }^{3}$ Cardosos (1980); e Linhares e Silva (1980). e trabalhando com grande massa de fontes primárias, construiu outra imagem do Brasil colonial e imperial. Ao lado do latifúndio soberano, aparece uma diversidade de formas de uso do solo em escala pequena e média. Ao lado do trabalho compulsório, erguese uma legião de pequenos produtores livres, trabalhando ou não com mão-de-obra escrava. Ao lado da monocultura para exportação, sobressai uma grande produção de alimentos voltada para a subsistência e para o mercado interno. Em vez de uma área prosternada ante Portugal, inteiramente subjugada aos desígnios deste, surge um Brasil complexo. Entre o senhor e o escravo, imiscuem-se grupos sociais que tornam o quadro bastante matizado. Comerciantes residentes no Brasil que se enriquecem com o comércio atlântico de escravos e com o mercado interno; pequenos e médios produtores rurais com ou sem escravos, muita vez trabalhando ao lado deles; escravos proprietários de escravos; diversificação das atividades econômicas; insustentabilidade do conceito de ciclo econômico. Eis algumas das conclusões alcançadas pelos autores dessa literatura historiográfica nova ${ }^{2}$ em que se acham estudos ainda não publicados e concebidos após a dissertação de mestrado de Drummond, matriz de seu livro.

No Brasil, os trabalhos inovadores não são reconhecidos de pronto como tal. Daí a distância entre concepção e publicação interpostas por força do mercado editorial. Só bem recentemente as investigações desses historiadores vêm merecendo a atenção das editoras e, mais uma vez, não cabe cobrar de Drummond a atualização de seu livro à luz dos novos estudos. Apenas, poderse-ia esperar que considerasse, pelo menos, as brechas abertas por Ciro Flammarion Cardoso e Maria Yedda Linhares que, já na década de 1970, apontaram a existência de uma dinâmica interna que pressupunha certa independência em relação aos movimentos externos, bem como interstícios na economia e sociedade da colônia e do império ocupados pelo pequeno produtor livre e pela produção mais diversificada para o mercado interno. ${ }^{3}$ Por outro lado, é oportuno observar que a disponibilidade de terra, mesmo que aparentemente infinita, era apenas teórica. Na prática, havia obstáculos a seu uso livre, como os intricados ecossistemas, animais invertebrados (a saúva, por exemplo, tão bem analisada por Warren Dean em $A$ ferro e fogo) e os índios, que não eram pacatos como fazem crer certos estudiosos da cultura.

A ucronia concebida por José Augusto Drummond, segundo a qual uma sociedade com significativo contingente de pequenos e médios proprietários e produtores estáveis, ainda que fosse coarctada pelo latifúndio, o trabalho escravo e a monocultura para exportação, conseguiria manter ou recuperar a fertilidade do solo, esfuma-se porque as investigações mais recentes mostram que esse contingente existiu, mas não usou a terra de forma mais 
prudente ou menos predatória que os latifundiários. Entre os pequenos e médios produtores também vigorou a lógica econômica européia. Em outras palavras, eles derrubaram florestas, usaram mal o solo, provocaram erosão, turvavam as águas, causaram assoreamento dos ecossistemas aquáticos continentais, empobreceram a biodiversidade, tanto quanto os grandes senhores de terras, escravos e manufaturas. Se os pequenos não contaram com a tecnologia mais cara dos grandes, se não dispuseram de copiosa quantidade de tecnologia rudimentar e de numeroso exército de escravos, detiveram, todavia, uma arma poderosíssima, de uso gratuito e democrático desde a primeira leva de invasores: o fogo. O próprio Drummond (pp. 55-6, 62) observa, com muita propriedade, que

... a facilidade com que os portugueses adotaram ou adaptaram a 'coivara' nas suas culturas de exportação e de subsistência mostra, entre outras coisas, que o 'solitário' colono português absorveu sofregamente uma prática tecnológica dos indígenas que ele mesmo classificava de 'selvagem' ... a 'coivara' dos portugueses se mostrou altamente predatória para as florestas brasileiras, pois tinha uma lógica mercantilista incompatível com a capacidade de regeneração natural das florestas. ... Os portugueses queimavam as florestas, limpavam o terreno, introduziam a cana e exploravam cada lote até a exaustão.

Conquanto o fogo tenha representado sempre uma ameaça aos ecossistemas vegetais, antes mesmo que os hominídeos se constituíssem em família zoológica, a letalidade de seu uso antrópico limita-se ou à perda de controle sobre ele ou à sua associação a uma visão mecanicista de mundo. Não foi apenas com os ameríndios que os europeus aprenderam a usá-lo. Basta lembrar o caso da ilha da Madeira, literalmente queimada no século XV, antes da montagem da máquina colonial portuguesa no Brasil. Se, por um lado, podemos redimir Drummond por não ter incorporado a suas análises a complexidade da economia e da sociedade colonial e imperial, como desculpar os novos historiadores da economia, da sociedade, da política e da cultura, que, contando já com literatura razoável acerca de eco-história, notadamente no exterior, ignoram este novo terreno e continuam entendendo as antropossociedades de maneira idealista, como se fossem elas apenas espírito ou cultura desprovida de infra-estrutura física e biológica. Na condição de eco-historiador, Drummond brada a realidade da natureza não-humana aos idealistas, culturalistas e historicistas.

O terceiro postulado da história ambiental que ele aponta são as interações do quadro de recursos naturais úteis com os diferentes estilos ou níveis civilizatórios das sociedades humanas. Logo de início, adverte que "os historiadores ambientais fogem do determinismo natural, tecnológico ou geográfico, mas se recusam 
a ignorar a evidente influência dos quadros de recursos naturais na história e na cultura das sociedades humanas." Segundo ele, a espécie humana conta com uma ferramenta de extrema eficácia para explorar e destruir a natureza: a cultura. Entendo que o Homo sapiens sapiens, agindo coletivamente, constrói culturas ecologicamente sustentáveis ou insustentáveis. Nos dois casos, explora a natureza, como, de resto, fazem todos os seres vivos. Assim, não há natureza intocada, com ou sem a presença dos hominídeos. Eis-nos, então, perante um dilema insuperável, talvez, mas salutar: o ser humano tem um pé no reino da cultura e outro no da natureza. A estrutura do corpo humano compõese de elementos presentes na origem e no desenvolvimento do universo físico e que nos ligam também aos animais. A presença, em nosso corpo, do físico e do biológico só pode ser explicada à luz de um processo histórico. Um desenvolvimento complexo e não-linear do universo físico desembocou na vida, que, por sua vez, originou os hominídeos e o Homo sapiens sapiens com seu cérebro hipercomplexo constituído de três níveis superpostos e de dois hemisférios. Uma espécie, enfim, cujo cérebro apresenta capacidade de aprendizado maior que os de outros animais, e que estabelece uma ponte entre natureza e cultura. A etologia animal vem mostrando que a sociedade é um fenômeno extremamente generalizado na natureza, que todo ser vivo tem capacidade de aprender e que a cultura pode eventualmente aparecer entre certos primatas. Perdemos a primazia em tudo, exceto, talvez, no fato de contarmos com um cérebro capaz de produzir culturas que explorem a natureza além de seus limites de auto-regeneração. Nenhum animal, ao que se saiba, foi capaz de desenvolver modos de vida ecologicamente insustentáveis. As crises ambientais que assolaram o planeta antes da constituição dos hominídeos enquanto família zoológica se devem a fenômenos astronômicos, climáticos e geológicos, como bem demonstrou Edward Wilson (1994).

Em resumo, somos o mais acabado elo entre natureza e cultura, entre história fisico-químico-biológica e história antropossocial. Assim, a cultura aparece como continuação da natureza em outro plano, como epifenômeno, quase. Entendida como o conjunto das criações materiais e imateriais humanas, passa a ser superestrutura, sendo o físico e o biológico a infra-estrutura. Na dimensão diacrônica, a história do universo e a nossa história interpenetram-se. Se, por um lado, é um equívoco naturalizar as sociedades dos ameríndios porque são constituídas por seres humanos e fatalmente produzem cultura, por outro, é um equívoco culturalizar absolutamente o europeu, porque, humano, ele também é natureza. São pertinentes, pois, nos dias de hoje, tanto a crítica ao naturalismo do bom selvagem quanto ao culturalismo da missão civilizatória do europeu. 
Golpeando o idealismo reducionista e ingênuo de algumas correntes dos movimentos de defesa do meio ambiente, José Augusto Drummond demonstra que os povos ameríndios pertenciam e pertencem (os que restaram) à espécie Homo sapiens sapiens. Possuíam e possuem valores culturais como todas as antropossociedades. Não se viam como bons ou maus. A exemplo dos ocidentais, também julgavam. Como toda antropossociedade, as ameríndias extraíam e consumiam recursos da natureza não-humana e também humana (através da antropofagia, por exemplo), produzindo impactos ambientais. Não se pode mais pensar em harmonia de qualquer antropossociedade com a natureza nãohumana. Pressupondo entrosamento perfeito entre as partes, sem fricções nem desgastes, harmonia é um conceito oriundo da física clássica e importado para a ciência humana da natureza humana. Nenhum ser - humano ou não-humano — vive em harmonia com o ambiente. Pode-se, no entanto, falar em modos de vida em equilíbrio dinâmico. A maioria das nações indígenas da América logrou criar culturas ecologicamente sustentáveis, inclusive o poderoso império inca. Por outro lado, uma cultura pode se autodestruir ao ultrapassar os limites da sustentabilidade, como mostra Ponting (1995), ao analisar a antropossociedade que se instalou na ilha de Páscoa. Destino semelhante parece ter acometido os maias, na América Central.

Em seu livro, Drummond perscruta o modo de vida dos povos construtores de sambaquis, que viviam agarrados à costa e aos ambientes dos quais retiravam recursos para sua existência. Esses povos acabaram sendo desalojados, no caso da meso-ecorregião estudada, pelos tupinambás e pelos goitacases (sei muito bem que as línguas ameríndias não conheciam plural, mas, como sou usuário do português, pluralizo os nomes). Os tupinambás praticavam regularmente a agricultura de coivara, demonstrando bom conhecimento dos solos e das variações climáticas. Todavia, não se pode afirmar que tenham passado completamente pela revolução neolítica, já que a coleta, a pesca e a caça continuavam sendo fontes significativas de recursos para o seu sustento. Os goitacás, por sua vez, viviam basicamente da coleta, da pesca e da caça, praticando uma agricultura rudimentar como complemento, se tanto. A dar-se crédito ao controvertido "Roteiro dos Sete Capitães" (ver nota 1), impressionam a rica biodiversidade faunística e o papel que representava na alimentação dos índios goitacás. De mais a mais, a relação espaço-recursos-população era francamente favorável ao último componente do trinômio, isto é, à população. É com reservas, pois, que encaro a extensão aos goitacás e outros povos do grupo gê dos cálculos efetuadas por Warren Dean para os tupinambás. As estimativas mínima e máxima de Dean para a densidade demográfica destes nos litorais 
futuramente paulista e fluminense oscilam em torno de 4,8 a 5,3 habitantes por quilômetro quadrado. Levando-se em conta que a ocupação indígena concentrou-se quase que exclusivamente nas planícies costeiras, mais propícias, pode-se calcular entre 57 mil a 63 mil a população absoluta dos tupinambás em 1500. Estendendo-se estes valores aos goitacás e a outros povos nativos do "retângulo dobrado", o número de habitantes ascenderia, na mesma data, a 150 mil.

Deve-se ter em mente que as informações sobre os tupinambás e tupiniquins são bem mais numerosas e ricas do que sobre os goitacás. Seja como for, não é temerário imaginar que o comportamento demográfico dos tupis e dos gês apresentasse similaridade. Contudo, não se pode esquecer que os goitacás habitavam a maior planície do território do futuro estado do Rio de Janeiro. Planície aluvial coberta de campos nativos e lagoas, excelentes hábitats para herbívoros e peixes. Chego, pois, à conclusão de que os goitacás viviam em situação muito mais confortável, no que diz respeito a recursos disponíveis, que os tupinambás, habitantes de uma planície alongada mas estreita. Além do mais, a agricultura tinha peso bem maior no modo de vida deste que no dos goitacás, já que o ambiente habitado pelos primeiros induzia ao cultivo de plantas, ao passo que o dos segundos inibia tal atividade. Mais uma conclusão: os tupinambás devem ter exercido pressão bem maior que os goitacás sobre a natureza não-humana, notadamente através do fogo.

Mesmo reconhecendo que os povos ameríndios não foram neutros e inofensivos no tocante aos recursos naturais, Drummond (p. 42) conclui que

... a população indígena do atual território fluminense era grande, antiga e tinha tecnologia agrícola mais do que suficiente para alterar — embora não para destruir — qualquer 'equilibrio ecológico natural' porventura existente na região antes de sua presença ... grande parte das florestas virgens do continente americano que impressionavam tanto os europeus recém-chegados tinha sido em algum grau modificada pela agricultura de 'coivara'. Ainda assim, essa população indigena não foi um fator de disrupção dos ecossistemas locais.

Os fatores apontados pelo autor para que tais povos não ultrapassassem os limites da sustentabilidade ambiental são os seguintes: a) economia exclusivamente de subsistência; b) agricultura incipiente, com poucas espécies domesticadas e pequenas áreas cultivadas, já que a disputa por terras litorâneas entre povos distintos não permitia utilização mais intensa delas; c) abundância de recursos do litoral nos estuários, mangues, lagoas, rios e baías, poupando as florestas e tornando a agricultura atividade apenas suplementar; d) desconhecimento de animais de pasto domesticados; e) uso de tecnologia rudimentar e pouco eficaz na transformação do ambiente, 
com exceção, quiçá, do fogo; e f) crença em entidades sagradas protetoras da natureza. Enfim, uma população ameríndia relativamente numerosa viveu em terras futuramente fluminenses por longo período, com uma tecnologia medianamente impactante, incapaz de suprimir ou alterar radicalmente a cobertura vegetal nativa e de destruir os demais recursos ambientais. Aos olhos dos europeus, acostumados a grandes transformações do meio ambiente em seu continente de origem, a natureza da América pareceu um paraíso íntegro habitado por seres anteriores ao pecado original ou semi-humanos ou não-humanos, dependendo da interpretação. Mas, seja ela qual for, viviam estes povos em estado pré-civilizacional. Por mais fascinante que fosse aquela natureza luxuriante, ela deveria ser dominada, domesticada e profundamente transformada para ser integrada à civilização. Recorrendo apenas a um exemplo - a coivara - para justificar a diferença entre os modos de vida dos povos ameríndios e europeus, acionada numa economia de subsistência, abria clareiras no interior de florestas; numa economia de mercado, removia florestas inteiras.

Outro traço da história ambiental destacado por José Augusto Drummond é o emprego de grande variedade de fontes. Menciona censos populacionais, econômicos e sanitários, inventários de recursos naturais, imprensa, documentos governamentais, diários e correspondência, mitos e lendas, relatos de viajantes, exploradores e cientistas europeus, memórias, inventários de bens e heranças, escrituras de compra e venda de terras, testamentos, descrições de dietas, roupas, moradias, mobiliário, ferramentas e técnicas produtivas, estudos sobre doenças, projetos e memoriais descritivos de obras, listas de bens comercializados, romances, desenhos, pinturas, registros climáticos... Arroladas assim, as fontes mostramse intermináveis. Por experiência própria, ensaiei uma tipologia. Examinei as fontes úteis para o eco-historiador de dentro, a partir da intenção consciente ou inconsciente dos que as produziram. Procedi à crítica externa e interna delas, não com o fim positivista de descobrir se são fidedignas ou apócrifas, mas para infundir-lhes vida, construir sua história e, a partir dela, construir outras histórias.

Quanto ao caráter externo, o ponto de partida e de chegada do eco-historiador é a fonte ambiental — como informação, no início; como explicação, no final. Pode-se praticar a eco-história sem conhecer o terreno estudado. A investigação, porém, não terá a mesma clareza que o conhecimento do espaço pode proporcionar. O ambiente estudado, em si mesmo, contém informações de primeira qualidade. Fala das transformações por que passou um ecossistema ou uma ecorregião, como preconiza William Cronon. Referindo-se a um professor nada ortodoxo que teve muita influência em sua formação, Simon Schama (1996) diz que ele considerava a paisagem como o arquivo dos pés. A bem dizer, 
não existe tal arquivo. Existe, sim, um arquivo de documentos que, além de ser explorado pelo sentido da visão, também pode ser vasculhado com os pés (de preferência, descalços), vale dizer, com o tato, o olfato e o paladar, sentidos transformados em plebeus nos métodos de inspiração cartesiana que invadiram as ciências humanas da natureza não-humana e das antropossociedades. Descartes (1990) situa a visão como o mais completo sentido no processo de conhecimento. A desmesurada valorização do olho, em primeiro lugar, do ouvido, em segundo, lançou no ostracismo o nariz, a língua, as mãos e os pés. Já no princípio do século XX, O historiador inglês Arnold J. Toynbee (1970) percorreu a Itália e a Grécia a pé para melhor conhecê-las. O conselho que dá aos estudiosos viajantes é: "lute com unhas e dentes para ter permissão de viajar naquilo que é tecnicamente o meio menos eficiente". Drummond usa bem este tipo de fonte, sobretudo quando se refere às atrações dos parques nacionais fluminenses, e exercita neste uso o trabalho de campo, outra característica da história ambiental arrolada por ele.

Um segundo tipo são as fontes-objeto, isto é, utensílios, armas, vestimentas, esculturas, mobiliário, edificações, tudo aquilo, enfim, que denominamos de bens móveis. As peças de um sítio arqueológico ou um prédio podem falar mais do que muitos textos escritos. Os historiadores, porém, acostumaram-se a ouvir o que estes documentos têm a dizer por intermédio de textos escritos por especialistas em arqueologia, sigilografia, historiadores da arte e das técnicas.

As fontes orais também suprem enorme lacuna deixada pelos documentos escritos. Como os eco-historiadores lidam com assuntos considerados insignificantes, nem sempre encontram registros pertinentes em fontes escritas e precisam, portanto, recorrer a depoimentos de portadores de informações para obter os dados de que necessitam. Se os informantes do período estudado estiverem mortos, a tradição oral e a toponímia podem ser de extrema valia.

Por mais variada que seja a gama de fontes usadas hoje pelos historiadores, as escritas continuam a desfrutar de grande prestígio. Entende-se por fonte escrita um documento vazado em caracteres de qualquer sistema gráfico, registrado sobre qualquer material e redigido manualmente ou mediante engenhos. Com o aperfeiçoamento dos meios de reprodução, as fontes escritas adquiriram grande mutabilidade, podendo passar de manuscritas a datiloscritas, digitadas, impressas e reprografadas. Grande, também, é a variedade de fontes iconográficas a que pode recorrer o eco-historiador. Ávido pela construção de seu objeto, utiliza cartas, mapas, plantas e planos, retratos (manuscritos e impressos), fotografias e filmes.

Se encararmos os documentos do ponto de vista interno, verificamos que o eco-historiador é um onívoro, serve de fontes 
fortes e fracas (com muitas ou poucas informações quantitativas ou qualitativas), fontes isoladas, fontes seriadas, fontes-monumento... Se bem que não faça uso de repertório tão diverso em seu livro, Drummond está cônscio de seu potencial e de suas virtualidades.

Como salientei, Devastação e preservação ambiental no Rio de Janeiro destina-se principalmente ao leitor não-especialista. Mesmo assim, creio que o autor não poderia dispensar referências às fontes e à bibliografia. Em várias passagens, eu, colocando-me na condição de leitor comum, desejei saber a procedência da informação e não a obtive. Em que fonte ou fontes se baseia o autor para afirmar, por exemplo, que, em 1575, os portugueses massacraram os goitacás que resistiam à conversão e teimavam em negociar o pau-brasil com os franceses? Quem é o viajante europeu que, em 1650, contou quarenta engenhos na região de Campos dos Goitacases? De onde provém a informação de que as terras de Itaperuna e do noroeste fluminense foram as maiores produtoras mundiais de café no período 1870 a 1880 ?

Há também, ao que me parece, alguns equívocos factuais. O inhame, que dá por nativo do Brasil, é o cará, pertencente à família das dioscoriáceas, ou o inhame propriamente dito, da família das aráceas e procedente da Ásia com passagem pela África? O pau-brasil (cujo nome científico é Caesalpinia echinata e não Caesalpina echinata), faz parte, segundo o autor, de uma família que só existia em alguns trechos maduros da Mata Atlântica e apenas de São Paulo para o Norte. Quero crer que trocou gênero por família, já que o pau-brasil pertence à família das leguminosas, de ampla dispersão pela América tropical, e que, para fins de padronização de nomenclatura, vem sendo denominada de fabácea, com suas três subfamílias prestes a ganhar status de família. Assim, o pau-brasil passaria para a família Caesalpineaceae. Conforme Henrique Pimenta Veloso, o gênero Caesalpinia é originário da África, conquanto tenha viajado para o Brasil por seus próprios meios, sem ajuda antrópica. Mário Maestri (1991) informa que os europeus já conheciam a Caesalpinia sappan desde o século XI, importando-a a altíssimos preços através do mar Vermelho. Davamthe os nomes de verzino, brasil, bersil. Parece que só assim se pode explicar a tão rápida descoberta das propriedades tintoriais desta madeira pelos portugueses, já que os nativos não a empregavam como corante. Certamente a semelhança com a árvore do mesmo gênero, conhecida dos europeus há tanto tempo, motivou Gaspar de Lemos e Cabral a transportarem toras para Portugal no torna-viagem.

Em outra passagem, Drummond sustenta que "o grande impulso para uma ocupação mais intensa do Rio de Janeiro foram as sesmarias concedidas em 1627, entre a baía de Guanabara e a boca do rio Paraíba do Sul, aos chamados 'Sete Capitães'. Nessas 
propriedades da planície costeira fluminense os sesmeiros introduziram grandes plantações de cana-de-açúcar."

Ora, sabe-se que os capitães possuíam sesmarias no recôncavo da baía do Rio de Janeiro e no caminho de Cabo Frio, onde cultivavam cana e fabricavam açúcar. No entanto, as sesmarias que requereram em 1627 situavam-se entre o rio dos Bagres, atual Macaé, e o rio Iguaçu, hoje lagoa do Açu. De maneira nenhuma elas se estendiam da baía de Guanabara à foz do rio Paraíba do Sul. Tampouco introduziram os novos sesmeiros grandes plantações de cana. Eles ocuparam os campos nativos de planície com o gado. No século XVII, a cana-de-açúcar era ainda uma atividade secundária em relação ao pastoreio, como se verifica no "Roteiro dos Sete Capitães" e na "Representação" de André Martins da Palma. Por fim, o rio Paraíba do Sul não conta com afluente no Espírito Santo nem José Cândido de Carvalho é um cronista da decadência do café.

Todo estudo de história ambiental é pioneiro no Brasil. Por isso, devemos atentar mais para os seus méritos do que para as suas falhas. Na discussão sobre as florestas como símbolos de civilização ou de ausência dela, levantada por Cláudia Heynemann e José Augusto Drummond, fico com a posição deste último: são fortes os indícios de que o morro da Tijuca só foi reflorestado por causa da escassez de água que afetou a cidade do Rio de Janeiro e não para ostentar aos países europeus um Brasil mais civilizado, ainda que esta concepção povoasse a mente da elite intelectual. É bastante feliz, igualmente, a imagem transmitida por Drummond de que os parques nacionais do Rio de Janeiro sofrem de redundância ecossistêmica por protegerem amostras de mata ombrófila densa de terras altas. Sem dúvida, Devastação e preservação ambiental no Rio de Janeiro representa valiosa contribuição ao conhecimento do meio em que se movimentaram os povos ameríndios e os invasores europeus. Profundamente transformado hoje, constitui esse meio a casa de um expressivo contingente populacional, casa que a maioria deseja continuar demolindo e que uma minoria se esforça por restaurar e proteger. 


\section{REFERÊNCIAS BIBLIOGRÁFICAS}

Cardoso, Ciro Flamarion 1980

Castro Faria, Sheila Siqueira de 1994

Castro Faria, Sheila Siqueira de 1986

Castro, Hebe Maria Mattos de 1995

Castro, Hebe Maria Mattos de 1987

Couto Reis, Manoel Martins do 1785

Cronon, William 1983

Crosby, Alfred W. 1993

Crosby, Alfred W. 1973

Dean, Warren 1996

Dean, Warren 1989

Descartes, René 1990

Drummond, José Augusto 1977

Drummond, José Augusto 1988

Florentino, Manolo 1997

Fragoso, João Luís Ribeiro e Florentino, Manolo 1993

Fragoso, João Luís Ribeiro 1992
'As concepções acerca do sistema econômico mundial: a preocupação obsessiva com a extração do excedente'. Em José do Amaral Lapa (org.), Modos de produção e realidade brasileira. Petrópolis, Vozes.

A colônia em movimento: fortuna e família no cotidiano colonial. Tese de doutoramento, Niterói, ICFC/UFF.

Terra, trabalho em Campos dos Goitacases, 1850-1920.

Dissertação de mestrado, Niterói, ICFH/UFF.

Das cores do silêncio: os significados da liberdade no Sudeste escravistaBrasil, século XIX. Rio de Janeiro, Arquivo Nacional.

Ao sul da história: lavradores pobres na crise do trabalho escravo. São Paulo, Brasiliense.

'Descrição geográfica, política e cronológica do distrito dos Campos Goitacás, que por ordem do Ilmo. Exmo. senhor Luiz de Vasconcellos e Souza do conselho de S. Majestade, vice-rei, capitão-general do mar e terra do Estado do Brasil etc. se escreveu para servir de explicação ao mapa topográfico do mesmo terreno, que debaixo da dita ordem se levantou'. Rio de Janeiro, s. ed.

Changes in the land: Indians, colonists and the ecology of New England. Nova York, Hill \& Wang.

Imperialismo ecológico: a expansão biológica da Europa - 900-1900. São Paulo, Companhia das Letras.

The Columbian exchange: biological and cultural consequences of 1942. Wesport, Greenword Press.

A ferro e fogo: a bistória e a devastação da Mata Atlântica brasileira. São Paulo, Companhia das Letras.

A luta pela borracha no Brasil. Rio de Janeiro, Nobel.

El tratado del hombre. Madri, Alianza Editorial.

Devastação e preservação ambiental no Rio de Janeiro: os parques nacionais do estado do Rio de Janeiro. Niterói, Eduff.

National parks in Brazil: a study of 50 years of environmental policy (with case studies of the National parks of the state of Rio de Janeiro). Tese de mestrado, Evergreen State College.

Em Costas Negras: uma história do tráfico de escravos entre a África e o Rio de Janeiro. São Paulo, Companhia das Letras.

O arcaísmo como projeto: mercado atlântico, sociedade agrária e elite mercantil no Rio de Janeiro, 1790-1840. Rio de Janeiro, Diadorim.

Homens de grossa aventura.

Rio de Janeiro, Arquivo Nacional. 


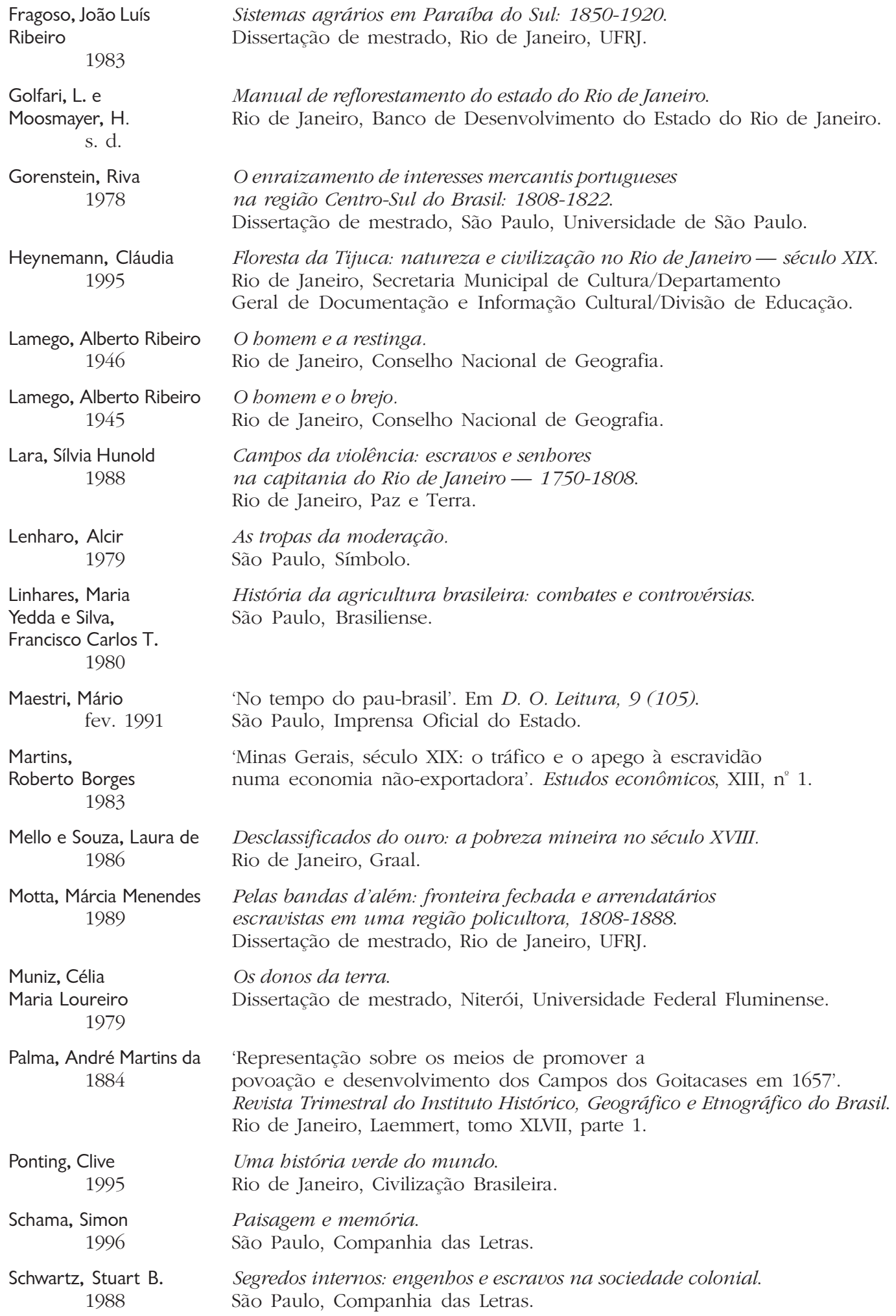


ARTHUR SOFFIATTI

Soffiati, Arthur

1996

Thompson, E. P.

1987

Toynbee, Arnold J. 1970

Turner, Frederick 1990

Veloso, Henrique Pimenta.

1992

Veloso, Henrique Pimenta; Rangel Filho, Antonio Lourenço Rosa

e Lima, Jorge

Carlos Alves

1991

Wilson, E. 1994
O nativo e o exótico: perspectivas para a história ambiental na ecorregião Norte-Noroeste fluminense entre os séculos XVII e XX. Rio de Janeiro, IFCS/UFRJ.

Senhores e caçadores.

Rio de Janeiro, Paz e Terra.

Experiências

Petrópolis, Vozes.

O espirito ocidental contra a natureza: mito, história e as terras selvagens. Rio de Janeiro, Campus.

Manual Técnico da vegetação brasileira.

Rio de Janeiro, Fundação Instituto Brasileiro de Geografia e Estatística.

Classificação da vegetação brasileira, adaptada a um sistema universal. Rio de Janeiro, Fundação Instituto Brasileiro de Geografia e Estatística.

Recebido para publicação em agosto de 1997. 